\section{Complementary and Alternative Medicine in Brazil: one concept, different meanings}

\author{
Medicina Alternativa e Complementar no Brasil: \\ um conceito e diferentes significados
}

\author{
1 Faculdade de Ciências \\ Médicas, Universidade \\ Estadual de Campinas, \\ Campinas, Brasil. \\ Correspondence \\ N. F. Barros \\ Departamento de Medicina \\ Preventiva e Social, \\ Faculdade de Ciências \\ Médicas, Universidade \\ Estadual de Campinas. \\ C. P. 6111, Campinas, $S P$ \\ 13083-970, Brasil. \\ nelfel@uol.com.br
}

\begin{abstract}
This article discusses the various meanings ascribed to the concept of Complementary and Alternative Medicine (CAM) in Brazil, where research on this theme has a limited tradition in terms of influences from anthropology, sociology of knowledge and epistemology, and sociology of CAM and clinical medicine. By means of the concepts identified in the literature, we elaborated a table with types of meanings. The terms Alternative Medicine and Complementary Medicine were found in more than one of the types in the table. Alternative Medicine identifies a model of medical practice influenced by the social, political, and economic context and by the logic of scientific production based on opposing pairs. Beginning in the 1980 s, the important volume of reflections on official medical practice and the search for other forms of knowledge production led to the creation of the concept of Complementary Medicine. Its meaning is that of a new epistemological form of knowledge production between the official and alternative poles, a set of therapeutic practices, and confusion with the nomenclature for ancillary medical diagnostic tests, referred to in Portuguese as "complementary exams".
\end{abstract}

Complementary Therapies; Knowledge; Professional Practice
Nelson Filice de Barros 1

Everardo Duarte Nunes ${ }^{1}$

\section{Introduction}

The purpose of this article is to discuss the different meanings ascribed to the concepts of Complementary and Alternative Medicine (CAM) in Brazil. Interest in CAM has increased worldwide among users, researchers, funding agencies, and healthcare services $1,2,3$.

In Latin America in general, there are few researchers who have investigated this issue systematically. Most of the existing research output has been in the form of theses, dissertations, and books. In Brazil, CAM research has a limited tradition, although it has taken four directions. The first is influenced by anthropology and is the most extensive, since popular health practices and care have been studied since the 1940s 4,5,6,7,8,9. The second is more recent, but spans over a decade and is more influenced by the sociology of knowledge and the philosophy of science, discussing scientific medical rationality and alternative medical rationality $10,11,12,13,14,15,16$. The third direction is even more recent and is influenced by sociology. It aims to develop a sociology of CAM using both qualitative and quantitative research with health services users, different professionals, public and private managers, and health policy administrators $17,18,19,20,21$. The fourth is the most recent and is mostly influenced by clinical medicine in the search for evidence for potential use of CAM in specific treatments 22,23. 
Brazilian CAM research is guided by the belief that one form of medicine is not opposed to another. Therefore, in principle, the issue is not to denounce given practices or to nurture deeply-rooted love-hate feelings. Neither is it about self-promotion, as some Brazilian journalists insist 24 . It is not about pointing out the therapeutic potential of official or unofficial medical practices, but rather to socially bring alternative and complementary practices together in different contexts, taking the literature as its basis and including research with CAM practitioners.

\section{Materials and methods}

This article is the result of a survey to answer the following epistemological question: why do physicians with an allopathic background (with its clear-cut definition and social recognition) opt to practice some sort of CAM?

Rational knowledge in the perception of the world, in the general sense, is developed on the basis of oppositions (e.g., night and day, heat and cold, life and death, etc.). In the history of dual classifications, Cartesian rationalism, Bacon's empiricism, and Comte's positivism added their strengths to guarantee a more official nature to the physical and natural worlds as sources of knowledge, relegating the human and metaphysical worlds to the status of alternative knowledge. The presence of alternative knowledge was mostly felt in the fields that produced practices, beliefs, social symbols, and values. However, this has led to the possibility of more than one meaning for the same word, which in turn is the aim of our analysis, i.e., to reflect on the production of a polysemy for CAM 25 .

We used Bourdieu's approach to data classification and analysis $26,27,28,29$. Using the concepts of field and habitus, we produced macrosociological and micro-sociological analysis and found emerging relations between them. From a macro-sociological perspective, we situate CAM in the Brazilian health field by discussing the theories used in CAM studies, the institutions that produce CAM in the health field, and correlated fields that support CAM ideas and development. Using the habitus perspective, we developed an analysis showing the individual ways, behaviors, and beliefs concerning CAM, emphasizing the relationship between individual and social interactions.

In this study, we have organized the various terms found in both a general and a specific way. To identify these terms in a broader sense, we use a table of names and types (Table 1). In order to discuss these terms in a more specific dimension, we reflect on their relationships, correlations, and particular meanings. With the concepts collected, we produced the abovementioned table, which we used to discuss the different meanings of CAM.

The "scientific" type is formed by the set of concepts which the health field labels as "official". This official identification stemmed from the connection between medical knowledge and the modern state 30,31 and the creation of the concept of biomedicine 32 , which meant the union of experimental biological precision and the existential "imprecision" of medical practice.

The "antithetical" type was identified in the health field as alternative because its practices maintained a less formalized dimension and it was more focused on the symbolic universe of the health-disease process. We find a first conceptual imprecision here, since alternative knowledge dates back to rational production in opposing pairs, which tells us that there was always the possibility of alternative practices. However, the 1960s counter-culture movement produced the specific Alternative Medicine model, with alternative practices opposed to official and hegemonic ones. This process started at a specific time and place, since the Cold War was in force, with each side punishing and excluding certain practices. There was a growing awareness of the fallacy of the development and progress concepts, which produced environmental destruction and social misery. Those were very productive times for (epistemological) philosophy, raising questions which remained unanswered and generating insecurity in the Western cosmological structure. There was intense experimentation in the educational field, with alternative pedagogical initiatives, and in social and sexual behavior as well. Disillusionment in the health sector led to the search for alternatives to the high costs of medical treatment, the multinational cartels, medicalization and iatrogenics, and distancing of medical professionals from patients. Last but not least, there was a reappraisal of knowledge production models in the "harder" sciences like physics and biology and the human sciences like sociology and philosophy.

From the "antithetical" group came medical rationality and the new therapeutic models. In the early 1990s the conceptual matrix of medical rationality was produced, which enabled an important differentiation in the epistemological study of CAM in Brazil. A medical rationality consists of a cosmology, medical doctrine, morphology, physiology, or vital dy- 
Typologies and concepts of medical practice in the field of healthcare.

\begin{tabular}{|c|c|c|c|}
\hline Scientific type & Antithetical type & $\begin{array}{l}\text { Types of medical } \\
\text { rationality }\end{array}$ & $\begin{array}{l}\text { Types of new therapeutic } \\
\text { systems }\end{array}$ \\
\hline Biomedical medicine & Popular medicine & Biomedical medicine & Holistic medicine \\
\hline Scientific medicine & Folkloric medicine & Chinese medicine & Alternative medicine \\
\hline Allopathic medicine & Indigenous medicine & Ayurvedic medicine & Oriental medicine \\
\hline Western medicine & Aboriginal medicine & Homeopathic medicine & Parallel medicine \\
\hline Erudite medicine & Traditional medicine & & Sweet medicine \\
\hline Official medicine & Naturalistic medicine & & Interactive medicine \\
\hline Alternative medicine & Household medicine & & Energetic medicine \\
\hline Community medicine & Magic-religious medicine & & Spiritual medicine \\
\hline Integrative medicine & Simplified medicine & & Metaphysical medicine \\
\hline \multirow[t]{7}{*}{ Traditional medicine } & Informal medicine & & Vibration medicine \\
\hline & Non-official medicine & & Complementary medicine \\
\hline & Non-allopathic medicine & & Integrative medicine \\
\hline & Non-orthodox medicine & & \\
\hline & Non-biomedical medicine & & \\
\hline & Alternative medicine & & \\
\hline & Complementary medicine & & \\
\hline
\end{tabular}

namics and a diagnostic and therapeutic system 10. Armed with this conceptual corpus, it was possible to differentiate alternative medical rationalities and the set of alternative medical practices. Thus, the "rationality" type presents the medical models in their biological dimensions, such as morphology, physiology, and therapeutic systems, and philosophical dimensions such as medical cosmology and medical doctrine. As long as a medical activity possesses all these elements, it can be recognized as a medical rationality, while the absence of one of these elements positions the activity as a diagnostic or therapeutic practice.

The new therapeutic models present a set of names for the practices they employ to build the elements of rationality or simply operate as alternative diagnostics or therapeutics.

\section{Discussion}

As observed in numerous studies 33,34 and in our table, Alternative Medicine presents the following types: official, antithetical, and new therapeutic models. For each of these types, the name is ultimately responsible for constructing its meaning, which can be defined as something "in relation to" and not a thing in itself. Moreover, meaning does not exist in itself but is determined by ideological positions in play during the socio-historical process in which the words were produced. The meaning of words change according to the position in which they are used 35,36 .

The meaning of Alternative Medicine as used in the "official" type may be understood as the foundation of the first meaning of Alternative Medicine. For example, a reference search on MEDLINE suffices to understand its projection, since there is a long list of citations on alternative medicine in relation to diagnostic construction, alternative surgical interventions, and even alternative clinical treatments.

The second meaning of Alternative Medicine is expressed in the "antithetical" type, which functions as a space for reformulation/substitution of the official model that can thereby operate reforms of the management model or the technical assistance model. The greatest mentor of this meaning of Alternative Medicine in Latin America was Ivan Illich in his book Limits to Medicine: Medical Nemesis, the Expropriation of Health 37 , presenting strong criticism of the collective and individual iatrogenic process promoted by the official or biomedical model.

The third meaning of Alternative Medicine is in the typology of new therapeutic systems. If the biomedical model had enjoyed greater capacity in the past, this model probably would never have existed. The official type operated according to a logic based on exclusion, which did not recognize any alternative perspective that differed from those that permitted its in- 
ternal reformation. This increased the amount of conceptual confusion regarding the use of the Alternative Medicine concept until it became possible to differentiate between an alternative medical rationality and a non-biomedical alternative therapy. This differentiation clarified the structure of the new therapeutic systems based on elements and different rationality techniques.

This imprecision also repeated itself in relation to the concept of Complementary Medicine, differing in that it dealt with a more recent discussion, although originally the notion of scientific complementariness emerged in the late 1920s, as proposed by Louis de Broglie and Niels Bohr. Complementariness originates in physics, where research demonstrated that an electron has characteristics that are complemented by energy and matter. This notion indicated another construction of knowledge, no longer based on opposition and joined with other epistemological criticism 38.

In the early 1980s, science accumulated a major body of evidence that signaled an imprecision in science itself, and subsequently the volume of questions concerning Alternative Medicine could no longer be ignored 39,40,41,42. Hence, the need and desire to incorporate new therapeutic practices into the official medical systems helped create the concept of Complementary Medicine 43,44.

Originally, the concept was produced to transmit the logic of inclusion, as opposed to the exclusive logic of scientific epistemology 36,45 . This is obviously a confounding factor, because Complementary Medicine lacks the capacity of medical rationality, but is not only an alternative technique $9,10,46$. The logic of knowledge production is certainly more profound than the internal reforms of the antithetical type, since it proposes the incorporation of difference. This confusion was soon identified as a conceptual imprecision, more so after using the concept of Complementary Medicine to refer to a group of practices.

The health field in Brazil entered the 1980s with a confusion of meanings in Complementary Medicine. At times it had an epistemological dimension, and was therefore a group of categories and concepts, and at other times it had the dimension of a concept referring to a group of practices. When this imprecision was submitted to sociological observation, it was possible to perceive two perspectives: (1) Complementary Medicine, viewed as a modern synonym of Alternative Medicine in which the renomination of previously excluded practices would be fundamental for its incorporation into the official health services and (2) the maintenance of the original meaning of complementary logic that is being replaced by the concept of Integrative Medicine 47,48. In Brazil, the CAM concept shows yet another confounding element. In Portuguese, in medical practice, ordering an ancillary diagnostic test is referred to as a "complementary tests order". Thus, when one speaks of "complementary medicine", many health professionals interpret the term as part of the biomedical model. This may explain why some professionals working with CAM practices now refer to themselves as Integrative Medicine professionals.

\section{Resumo}

Este trabalho discute os diferentes significados do conceito de Medicina Alternativa e Complementar (MAC) no Brasil, onde pesquisa sobre este tema tem pequena tradição com influências da Antropologia, da Sociologia do Conhecimento e Epistemologia, da Sociologia das MAC e da Clínica. Por meio dos conceitos encontrados elaboramos um quadro de diferentes tipos de sentidos. Os nomes Medicina Alternativa e Medicina Complementar foram encontrados em mais de um dos tipos do quadro. A Medicina Alternativa identifica um modelo de prática médica influenciado pelo contexto sócio-político/econômico e pela lógica da produção científica do conhecimento com pares de oposição. A partir dos anos de 1980, o expressivo volume de reflexões sobre a prática médica oficial e a procura de outras formas de produção do conhecimento, levou à criação do conceito de Medicina Complementar. Seu significado é de uma nova forma epistemológica de produção do conhecimento entre os pólos oficial e alternativo, de um conjunto de práticas terapêuticas e de uma confusão com a nomenclatura dos exames que auxiliam no diagnóstico médico, chamados em português "exames complementares".

Terapias Complementares; Conhecimento; Prática Profissional 


\section{Contributors}

Both authors participated in the research and the writing of this paper.

\section{References}

1. World Health Organization. Legal status of traditional medicine and complementary/alternative medicine. Geneva: World Health Organization; 2001.

2. World Health Organization. National policy on traditional medicine and complementary/alternative medicine. Geneva: World Health Organization; 2002.

3. Committee on the Use of Complementary and Alternative Medicine by the American Public. Complementary and Alternative Medicine in the United States. Washington DC: Institute of Medicine of the National Academies Press; 2005.

4. Cabral D. A medicina teológica e as benzeduras. Revista Arquivos do Departamento de Cultura 1958; (109).

5. Maynard A. Medicina rústica. Rio de Janeiro: Editora Nacional; 1959.

6. Bastide R. Negros no Brasil: religião, medicina e magia. São Paulo: Edusp; 1971.

7. Oliveira ER. Doença, cura e benzedura: um estudo sobre o ofício da benzedeira em Campinas [Master's Thesis]. Campinas: Instituto de Filosofia e Ciências Humanas, Universidade Estadual de Campinas; 1983.

8. Queiroz MS. Curandeiro do mato, curandeiro da cidade e médicos: um estudo antropológico dos especialistas em tratamento de doenças da região de Iguape. Ciênc Cult (São Paulo) 1980; 32:31-47.

9. Queiroz MS. Estudos sobre medicina popular no Brasil. Religião e Sociedade 1980; (5):241-50.

10. Luz MT. Racionalidades médicas e terapêuticas alternativas. Rio de Janeiro: Instituto de Medicina Social, Universidade do Estado do Rio de Janeiro; 1993. (Série Estudos em Saúde Coletiva, 62).

11. Camargo Jr. KR. Racionalidades médicas: a medicina ocidental contemporânea. Rio de Janeiro: Instituto de Medicina Social, Universidade do Estado do Rio de Janeiro; 1993. (Série Estudos em Saúde Coletiva, 65).

12. Luz HS. Racionalidades médicas: a medicina homeopática. Rio de Janeiro: Instituto de Medicina Social, Universidade do Estado do Rio de Janeiro; 1993. (Série Estudos em Saúde Coletiva, 64).
13. Marques EA. Racionalidades médicas: a medicina ayurvédica. Tradicional arte de curar na Índia. Rio de Janeiro: Instituto de Medicina Social, Universidade do Estado do Rio de Janeiro; 1993. (Série Estudos em Saúde Coletiva, 75).

14. Luz D. Racionalidades médicas: medicina tradicional chinesa. Rio de Janeiro; Instituto de Medicina Social, Universidade do Estado do Rio de Janeiro; 1993. (Série Estudos em Saúde Coletiva, 72).

15. Camargo Jr. KR. Paradigmas, ciência e saber médico. Rio de Janeiro: Instituto de Medicina Social, Universidade do Estado do Rio de Janeiro; 1992. (Série Estudos em Saúde Coletiva, 6).

16. Tesser CD. Epistemologia contemporânea e saúde: a luta pela verdade e as práticas terapêuticas [PhD Thesis]. Campinas: Faculdade de Ciências Médicas, Universidade Estadual de Campinas; 2003.

17. Barros NF. Medicina complementar - uma reflexão sobre o outro lado da prática médica. São Paulo: Annablume/Fundação de Amparo à Pesquisa do Estado de São Paulo; 2000.

18. Barros NF. Da medicina biomédica à complementar: um estudo dos modelos da prática médica [PhD Thesis]. Campinas: Faculdade de Ciências Médicas, Universidade Estadual de Campinas; 2002.

19. Santos MG, Dias AGP, Martins MM. Conhecimento e uso da medicina alternativa entre alunos e professores de primeiro grau. Rev Saúde Pública 1995; 29:221-7.

20. Queiroz MS. O itinerário rumo às medicinas alternativas: uma análise em representações sociais de profissionais da saúde. Cad Saúde Pública 2000; 16:363-75.

21. Trovo MM, Silva MJP, Leão ER. Terapias alternativas/ complementares no ensino público e privado: análise do conhecimento dos acadêmicos de enfermagem. Rev Latinoam Enfermagem 2003; 11:483-9.

22. Samano EST, Goldenstein PT, Ribeiro LM, Lewin F, Valesin Filho ES, Soares HP, et al. Praying correlates with higher quality of life: results from a survey on complementary/alternative medicine use among a group of Brazilian cancer patients. São Paulo Med J 2004; 122:60-3. 
23. Elias MC, Alves E. Medicina não-convencional: prevalência em pacientes oncológicos. Rev Bras Cancerol 2002; 48:523-32.

24. Pinheiro D. Os riscos das terapias alternativas. Revista Veja 2002; 1 mai.

25. Bachelard G. O novo espírito científico. Rio de Janeiro: Tempo Brasileiro; 1968.

26. Ortiz R, organizador. Pierre Bourdieu. São Paulo: Ática; 1990. (Coleção Grandes Cientistas Sociais).

27. Bourdieu P. A economia das trocas simbólicas. São Paulo: Perspectiva; 1994.

28. Bourdieu P. Coisas ditas. São Paulo: Brasiliense; 1990.

29. Bourdieu P. Questões de sociologia. Rio de Janeiro: Marco Zero; 1983.

30. Foucault M. O nascimento da clínica. 5a Ed. Rio de Janeiro: Forense Universitária; 1988.

31. Santos BS. A crítica da razão indolente: contra o desperdício da experiência. São Paulo: Cortez; 2000.

32. Capra F. O ponto de mutação. São Paulo: Cultrix; 1988.

33. Ankster CW. Concepts in alternative medicine. Soc Sci Med 1986; 22:265-73.

34. Murray J, Shepherd S. Alternative or additional medicine? An exploratory study in general practice. Soc Sci Med 1993; 37:983-8.

35. Orlandi EP. Análise de discurso - princípios e procedimentos. Campinas: Pontes; 2001.

36. Low J. Alternative, complementary or concurrent health care? A critical analysis of the use of the concept of complementary therapy. Complement Ther Med 2001; 9:105-10.
37. Illich I. A expropriação da saúde. Nêmesis da medicina. Rio de Janeiro: Nova Fronteira; 1975.

38. Encyclopedia Britannica, Inc. http://www.eb.com/ (accessed on 09/Jan/1997).

39. Feyerabend PK. Contra o método. Rio de Janeiro: Francisco Alves; 1977.

40. Bunge M. Epistemología - curso de actualización. Montreal: McGill University, Foundation and Philosophy of Science Unit; n.d.

41. Moles AA. As ciências do impreciso. Rio de Janeiro: Civilização Brasileira; 1996.

42. Morin E. Introdução ao pensamento complexo. Lisbon: Piaget Institute; 1995.

43. Sharma U. Complementary medicine in the United Kingdom: practitioners and patients. London: Routledge; 1992.

44. Fulder SJ, Munro RE. Complementary medicine in the United Kingdom: patients, practitioners and consultants. Lancet 1985; 7:542-54.

45. Furnham A, Vicent C, Wood R. The health beliefs and behaviours of three groups of complementary medicine and a general practice group. J Altern Complement Med 1995; 1:347-59.

46. Jamil T. Medicina complementar - um guia prático. Barueri: Manole; 2001.

47. Weil A. Andrew Weil, MD on integrative medicine and the nature of reality. Interview by Bonnie Horrigan. Altern Ther Health Med 2001; 7:96-104.

48. Rees L, Weil A. Integrated medicine. BMJ 2001; 322:119-20.

Submitted on 16/Aug/2005

Final version resubmitted on 05/Dec/2005

Approved on 19/Dec/2005 